\title{
Enhancement Model of Employee Capabilities and Application of Company's New Culture in Realizing the Future Competitiveness
}

\author{
Iwan Sudirlan $^{1^{*}} \quad$ Syamsul Maarif $^{2} \quad$ M Joko Affandi $^{3} \quad$ Yandra Arkeman $^{4}$ \\ 1.Student of Doctoral Program of Business Management of SB-IPB, Jl. Raya Pajajaran Bogor, 16151 \\ 2.Professor of School of SB-IPB, Jl. Raya Pajajaran Bogor, 16151 \\ 3.Teaching Staff of Postgraduate of SB-IPB, Jl. Raya Pajajaran Bogor, 16151 \\ 4.Professor of Agricultural Industrial Technology of SB-IPB, Jl. Raya Pajajaran Bogor, 16151
}

\begin{abstract}
The condition of a business environment that is changing rapidly forms the turbulence for the business organization and makes the business people have to improve their ability to remain competitive and survive in a high competitive environment. The purpose of this study is to design and build a model for improving the employee capabilities and implementing a new corporate culture in realizing the future competitiveness. This study uses a soft system methodology (SSM) approach by involving the experts and the practitioners in the focus group discussion (FGD) or the depth interview to obtain the expert justification. The experts / practitioners include the Key positions as the strategic policy makers in Indosat and related practitioners, the experts / practitioners of Human Resource Management and the organizational theory, universities, and other institutions. This study produces the Conceptual Model with the elements of activity showing that increasing the employee capabilities and implementing a new corporate culture are needed in carrying out the operations that realize the competitiveness is the result of the Soft System Methodology. The capabilities of Indosat Ooredoo employees will experience a critical period if the existing employees and the new recruits have more than 5 years of experience reallocated or received early retirement. The sustainable competitiveness must be maintained by recruiting the new fresh graduates in accordance with the company's vision and priority programs. The recruitment to prepare the employee regeneration with the unique capabilities that are rare cannot be replicated and cannot be replaced.
\end{abstract}

Keywords: Change Management, Corporate Culture, HRM, SSM.

DOI: $10.7176 / \mathrm{EJBM} / 11-8-07$

Publication date:March $31^{\text {st }} 2019$

\section{Introduction}

The world's rapid environmental change requires the companies to adapt to the existing conditions. The environmental changes that occur include the technology, the information systems, the economics and politics, causing the new regulations and derivatives, so that the industry and the industry players can run well in their implementation.

To be able to survive in the competition with the environment and the technology that continues to change, the changes made by planning follow the Three Steps of Change Model (Lewin, 1947) namely Unfreezing $\rightarrow$ Moving $\rightarrow$ Refreezing. The implementation of the planned change management to make it easier to evaluate the development is for the successful change using Kotter's Eight Steps (Kotter's, 1996).

For the cultural change according to Lewin, it requires a change in leadership form in all aspects of life. The change in the consecutive majority ownership in one of the telecommunication companies in Indonesia is PT Indosat Tbk. The majority share ownership changed from Indonesia, the Public, STT Singapore, and Qatar Telcom, also influence the management of the company with different company policies (Lewin, 1947).

The condition of the business environment that is changing rapidly is forming the turbulence for the business organizations and making the business people have to improve their abilities to remain competitive and survive in the high competitive environment. The company's performance will be optimal if there is a match between the organization and its organizational environment and if there is no strategic gap. One of the best telecommunication companies in Indonesia in the face of turbulence that occurs is to improve the capabilities of the employees and their organizations continuously to be able to run a business sustainably by adapting internal and external environments, in this case the employees are expected to be able to expand their capabilities.

The purpose of this study is to design a conceptual model for enhancing the employee capabilities and implementing a new corporate culture in realizing the future competitiveness.

\section{Soft System Methodology (SSM)}

Soft System Methodology (SSM) is a descriptive approach (qualitative) that aims to explain the situation or reality, especially describing the human aspect in this case the cognitive thinking that is produced through a logical system, such as the aspects of strategy (vision, mission, culture, strategic goals, roles, norms, and values) and the analysis of other aspects such as other dominant (political) external conditions.

FGD in 2012 is conducted routinely with the number of participants of 450 employees from various levels, 
namely: Group Head, Division Head, Manager, Staff, and Customer Service Team. The FGD is carried out 50 times in stages and is scheduled at the Head Office and throughout the Regions. The Directors visits to Regional Offices in Medan, Banjarmasin, Jabodetabek, Bali, Bandung, Palembang, and Madura to meet in the Town Hall forums with the employees as well as the visits to the Gallery, to meet the Distributors, and the market visits.

This study also involves the in-depth direct interviews, as well as the group discussion or Focus Group Discussion (FGD) with deliberately selected respondents. The Focus Group Discussion (FGD) is carried out in order to gather information about the important matters in drafting the concept of enhancing the employee capabilities and the company's new culture to realize the company competitiveness. The participants in this FGD include: the key positions as the strategic policy makers in Indosat and related practitioners, HR management experts / practitioners and the organizational theory in order to draft the company's new cultural concepts to improve the competitiveness of the companies and universities and other institutions for drafting verification and validation of HR management and the company's new culture with a depth interview.

\section{Results and Discussion}

3.1 Indicator that has the lowest value on each variable

The variables analyzed in this study are the company vision and mission, the corporate culture, the change in controlling shares, the human resources (the employee recruitment, the work environment, the innovation and the employee creation, the employee habits), the infrastructure, and the corporate climate. The indicators with the lowest value on each variable, namely on the lowest indicator of the company's vision and mission, are still unscheduled, measurable, and still cannot be achieved from time to time. This means that in the transformation or organizational change it still needs to be done continuously and measurably, so that the targets and objectives of the company can be achieved properly. It is relevant with what to be conveyed in the theory of Anand namely dynamic capabilities through continuous improvement infrastructure. Evaluating the improvement strategy, identifying and deciding which infrastructure is important for continuous improvement initiatives must be measurable (Anand et al ,2009),

Likewise and Chen also expresses the view of Dynamic Governance (DG), an institution is said to be dynamic with the characteristics: (1) New ideas, fresh perception, continual upgrading, quick question, continuous learning, fast and effective execution, and unending change, and (2) Dynamic Governance is the key to success in the era of globalization and the era of technology (Likewise Neo and Chen, 2007). Moreover, Indosat Ooredoo is a company enganged in the ICT and digital sectors that develop very rapidly.

In the corporate culture variable, the lowest indicator is the increase in teamwork through the Achievement Motivation Trainning is still not done routinely every year, the lack of delivery of reports on the company's competitive performance against competitors (the strategy to compete with competitors and market share, the new ideas from the employees have not been evaluated, rarely conducted the training every year, and the submission of the company's financial performance report (the company stock performance) is not too open. This means that the Organizational Culture indicator, which is the increase in teamwork through the Achievement Motivation Training which should be done routinely every year, is still low and rarely done. The organizational culture is one of the important components in maintaining the performance and the competitive advantage. Moreover, if the Achievement Motivation Training is often carried out routinely, it can increase the employee motivation (Boniface, 2011).

The indicator that has the lowest value on the Changes in Controlling Shares is the non-routine delivery of the composition of share ownership in the company every quarter period.

On the Platform Change variable, How it Works and the Assessment System of the Lowest Performance indicator employees are still rarely recruiting every year, not always comparing the operating performance with the benchmark of other companies with the best performance in their classes, sometimes the punishment is not done to the employees with the inappropriate work results.

The indicator that has the lowest value on HR-Employee Recruitment is that the recruitment system in collaboration with universities and other companies which is still rarely done, the work rotation system is not in accordance with the ability of the employees to place the work positions which are not in accordance with the employee desires / not based on the ability of the employees. In addition, the promotion is not adjusted to the individual performance. In this case, the placement of the employees in the positions that match their competencies is one of the determining factors in improving the performance (Dhermawan et al ,2012). Related to the Reward and Punishment, state that in order to improve the employee performance, the companies should provide several alternative rewards given to the employees because with the increase in alternative rewards that can be obtained automaticall, so the employees will improve their performance in several aspects of the work. The punishment must also be given more firmly, it aims to create and improve the performance of more profitable and professional employees (Febrianti et al, 2014).

The lowest indicator value in the HR-Work Environment is a layout that is still a little less comfortable with the facilities provided some which have not felt comfortable to use. The working conditions are the situations 
where a good workplace includes the physical and non-physical conditions that can provide the pleasant, safe, peaceful and so on images, then it can spur the emergence of satisfaction in the employees who ultimately can have a positive influence on the employee performance. And vice versa, if the working conditions are bad, then the employees will not have the satisfaction in working (Dewi and Fitranto, 2013 in Sofyan, 2013). Furthermore, states that the work environment has a significant effect on the employee performance. When viewed from the competency of the employees that the employee competency testing is not only as a basis for the employee promotion and the employee recruitment, the employee knowledge is not always updated (Sarwani , 2016).

The lowest indicator value in the HR-Innovation and the creation of the employees / companies are those which feel they do not agree that the education is one of the indicators as the power to innovate, in accordance with the network modernization, some feel that they do not agree that there is an opportunity to convey the ideas and the creativity. This is not in accordance with the study conducted by Firmansyah which states that the better the pattern of innovation to be carried out, the better the performance of the employees (Firmainsyah , 2014).

The lowest values on the Training and Development of the employees are few who feel disagree that the training needs of the employees are evaluated annually based on the priority of the competency gaps and KPI achievement priorities, not all conduct the evaluation of the training program every month, some feel disagree that the company has the Training Information Systems for planning and implementing the training. Some feel disagree that there is a training to motivate the employees, to improve the relations between the employees and the superiors. The training should be given continuously to each employee, it would be better if the training is given from the beginning of the placement, so that the employees could easily adjust to their new works (Rachmawati, 2016,). A similar thing is conveyed by Julianry et al, with the training indicated that the employees can carry out work well, with the training can also change the gestures, attitudes and disciplines of the employees (Julianry et al, 2017).

The lowest indicator value in the HR-Habit of the employees is that the employees often ask the chairperson about the jobs that are poorly understood and seldom do the work according to their personality at work. The implementation of more leadership activities towards suppressing the employees can achieve the satisfaction in work, but not necessarily are able to bring a positive influence in forming the subordinate personalities to sincerely work towards the organizational goals. The lowest value on the infrastructure is that the office facilities are sometimes not in line with the development of the year, few feel disagree with the media of communication, the changes in office layout do not always make the employees comfortable (Brahmasari and Suprayetno, 2008).

The lowest indicator value in the company climate is that not every problem can be conveyed directly to the head / CEO of the company, in addition sometimes the management of the costs is not in line with the objectives of the company, the Employee Management Communication Forum every quarter is not always done, and the moving targets are evaluated every month by involving all departments' managers. According The communication can improve the employee performance, if the effective communication can be realized then the employee productivity will be higher (Ardiansyah , 2016),

The aspiration of the employees in 2012 conveyed in the FGD, the Leadership Meeting, and the Town Hall can be concluded:

The management hears that Indosat Ooredo as the company:

1. Has a strong brand image.

2. Has a poor network quality.

3. Needs to listen to the people.

4. Improves the products and the services.

5. Has the employees that want to be trusted and empowered.

6 . Has the loyal and passionate people.

The employees convey the company's situation with the opinion that can be concluded:

1. Technology - Plan to add more BTS and other 3G 900 networks.

2. Commercial - Plan to improve the gallery.

3. Wholesale - Positioning IM2 and Indosat MIDI.

4. Process - The procurement process is faster.

5. Technology - Faster handling of the network problem.

6. HR - A clear career path.

7. HR - Salary reaches the maximum limit.

8. HR - Planning outsourced employees.

The results obtained through the September 2016 Indosat Ooredoo employee questionnaire, obtained the problematic situation in the company environment:

1 . Vision and Mission.

2. Corporate culture.

3. Changes in controlling shares and changes to the platform of how the employee performance appraisal system works.

4. HR - recruitment - reward and punishment. 
5. Work environment and employee competency.

6. HR - innovation and employee creation, employee training and development.

7. HR - habits of employees / companies.

8. Infrastructure and corporate / organizational climate.

The situation that is considered to be problematic is the results of the employee FGD in 2012 and the results of the Indosat Ooredoo employee questionnaire in September 2016 which have the lowest indicator value for each variable.

\subsection{Problem Situation Expressed}

Furthermore, the problematic situation which is very complex with various purposeful activity systems is simplified and expressed in the form of the Rich Picture with various symbols, structures and processes. That a good rich picture must be made with (Checkland and Poulter, 2006):

1. Identifying the concepts and the ideas being studied;

2. Using symbols or icons that describe the ideas from SSM practitioners;

3. Using a connecting line between the concepts and between the main ideas accompanied by a brief explanation if needed.

Three types or stages of analysis carried out in order to understand the real world situations, namely First Analysis, Second Analysis, and Third Analysis (Checkland and Poulter, 2006).

3.2.1 Analysis - Intervention Analysis:

Clients

1. Researcher: Iwan Sudirlan

2. Advisory Commission

3. Indosat Ooredoo

Practitioner

1. Researcher: Iwan Sudirlan

Owners

1. Researcher: Iwan Sudirlan

2. Indosat Ooredoo, President Director \& CEO, and Director \& CHRO

In the stage of the first analysis, the researcher as part of the client conducts an intervention analysis, namely in the real world of Indosat Ooredoo's business activities daily as both the individual organic part of the company (employee) and also the company change agent. Of course, the reseachers as part and actors of change directly and indirectly intervene and can influence the process that occurs. The researcher is as the practitioner to ensure the use of Soft System Methodology. Likewise, as one of the owners of this research job, the researcher has an interest in ensuring that between the theory, the model and the real world in everyday business must be in harmony and in accordance with the actual and prevalent reality.

3.2.2 Analysis - Social Analysis:

Roles

1. Reseacher: Iwan Sudirlan, the exploration of the real world problems.

2. Indosat Ooredoo, digitizing Indonesia.

Norms

1. Employees work according to the Job Description.

2. The company complies with the Good Governance.

3. Work in accordance with the Company's Code of Ethics.

Values

1. Trust, Care, Fast, Passion to be the best, and Youthful Spirit.

3.2.3 Analysis - Political Analysis:

1. Policy of the controlling shareholders.

2. Board of Commissioners, Directors.

3. Indosat Workers Union.

4. Organizational Structure.

5. Company policy towards the employees and the partners.

3.3 Rich Picture Transformation of Indosat Ooredoo

Based on the situational analysis and the employee perception, with various purposeful human activities, the Rich Picture Transformation of Indosat can be explained in Figure 1. The rich pictures in their preparations pay attention to the general environment, the industry, and the company in accordance with the current competitive conditions.

1) The general environment that affects the problematic situation is:

- Uncertainty Situation, the situation of the global economic crisis and the rapid development of the telecommunication technology and information. 
- Regulation, both issued by the Ministry of Communication and Information, the Financial Service Authority, the Indonesian Stock Exchange, and the State Ministry of BUMN.

- Consultant, consulting services to Indosat Ooredoo Management covering the aspects: Legal, Image, Public Relation, Marketing, Sales Financial, and Business Process

- Non Telco Company, the company as a non-Telco competitor and as a partner such as Banking.

- Community / Customer, the users of individual, group or corporate telecommunication services.

2) The industry that plays a role is:

- Head Quarter Ooredoo, as the telco operator of the largest shareholder in Indosat Ooredoo influences the company policy.

- Competitor as Telco, the telecommunication operator as the competitor, namely: Telkomsel, XL, Three and others.

- TV Broadcaster, the provider of TV broadcasts as the partner of Indosat Ooredoo.

- Network Provider, the network service provider and other accesses such as: ISP Internet, backbone network provider, and network provider in offices and housing.

- Containt Provider, the provider of advertising, sms, survey, and other services.

- Facilities and Infrastructure (Vendors), the network provider, the information technology and the infrastructure access with the new technologies for the network modernization.

- Startup Company, a new company based on the communication application, namely: e-commerce, e-payment, e-ticket, e-travel, e-transport, and e-hotel.

- Dealer, the credit distribution companies or voucher.

- HP / Smartphone, the provider of convergent communication device.

3.4 Indosat Ooredoo

3.4.1 Management

Management consists of:

- Managing Director, the leader of Indosat Ooredoo company, plays a role in the transformation process and determines the HR to be chosen.

- CHRO, Chief Human Resource, plays a role in improving the employee capabilities and implementing the new culture.

- All Chiefs, carry out the transformation process at each directorate / office.

- Vision and Mission, the drivers to focus toward the customers and the digitalization of companies and Indonesia.

- Strategy, $4+1$ with a modernization program and increasing the HR capabilities.

- Program, supporting the corporate strategy execution.

- New Culture, the company's new values as part of the Program are in line with ongoing overall transformation.

- Re Branding, changes in the company logos and products according to the new culture.

- New Office, the new workspace, the concept of open space with bright colors and a relaxed work environment according to the new culture.

- Operations, the scope of routine work that runs the company's business.

- New Infrastructure and Technology, the modernization of satellite, cellular infrastructures, radio or cable transmission, and leased line with the support of increasing the employee capabilities or recruiting the new employees.

- Marketing, changing business concept and increasing the employee capabilities or recruiting the new employees.

- Sales, new incentive schemes and enhancing the employee capabilities or recruiting the new employees.

- Budget / Finance, the capital and operational costs must pay attention to the budget / finance.

- Employee (new spirit), the employees with capabilities and new culture are in the operational environment.

- New KPI / IPM, KPI employees to monitor the achievement of independent computer-based performance and to access my-info with the applications or information systems.

- Revenue and Profit, the increase in income and the profit of the company.

Furthermore, the real world situation in the telecommunications industry competition and the overall transformation process of Indosat Ooredoo which is previously unstructured is expressed more easily and with more complete information and is expected to also be identified in all systems of the activities that have the intentions to be poured into the root definition. In accordance with the opinion of Checkland and Poulter (2006), the rich picture of Indosat Ooredoo's transformation which is made by identifying the concepts related to the 
situation under study uses the icon or image according to the idea and uses the connecting lines between the concepts and between the main ideas with a brief explanation.

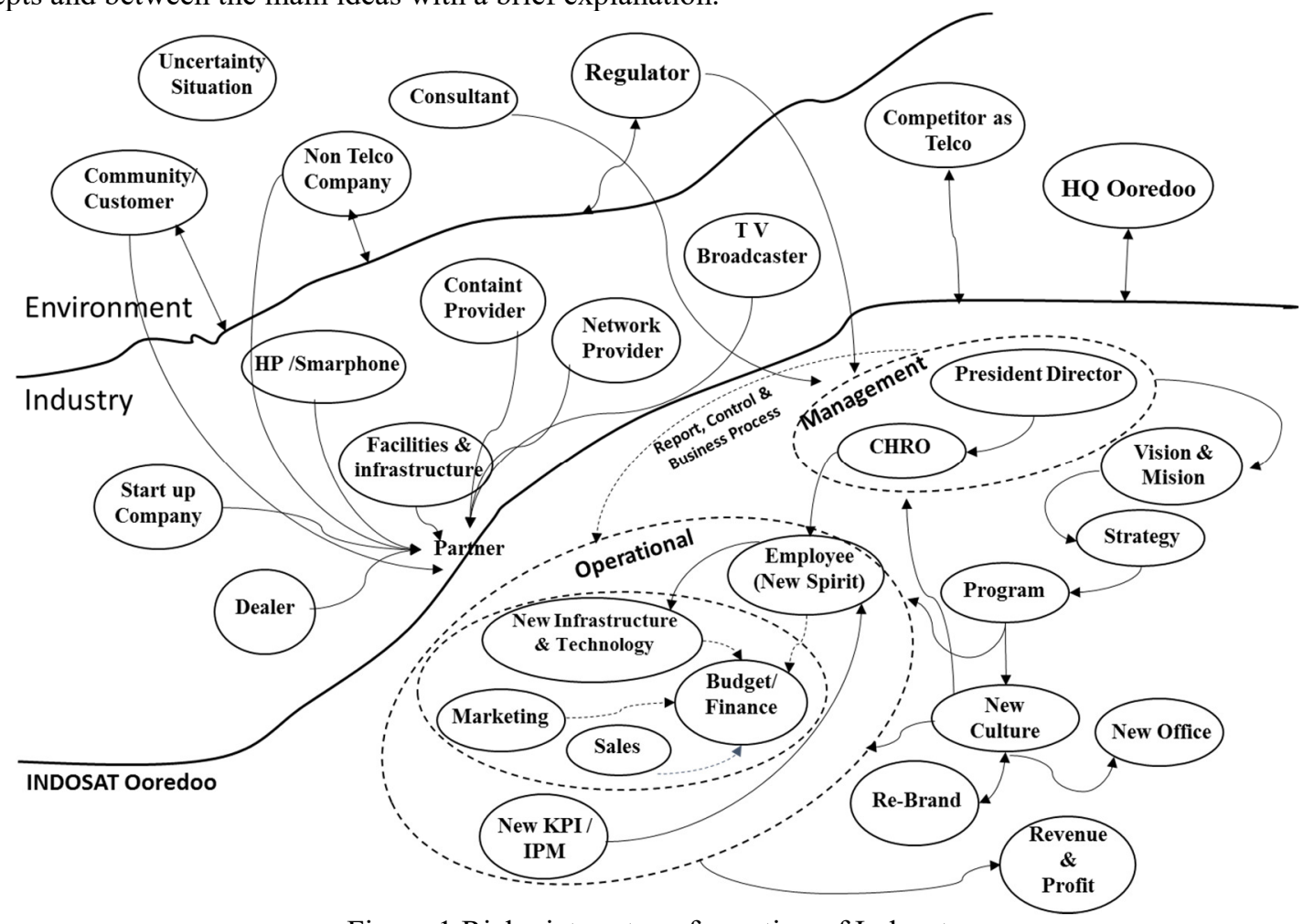

Figure 1.Rich picture transformation of Indosat.

\subsubsection{Root Definition}

The root definition is a clear statement about the activities that occur or may occur in the organization being studied, namely in Indosat Ooredo. The root definition is based on the information about the organization that has been collected previously.

3.4.3 PQR Analysis

A system that is owned and managed by the Telecommunication Company (Indosat Ooredoo) to improve the employee capabilities and the implementation of the company's new culture (P), by carrying out a complete transformation within the company $(\mathrm{Q})$, in realizing the company's competitiveness to become the leading digital telecommunication company in Indonesia (R). Furthermore, the root definition obtained will be used as the basis for making a conceptual model.

3.4.4 CATWOE Analysis

To reveal the system contained in Indosat Ooredoo, it is using CATWOE (customer, actor, transformation, worldview, owner, and environmental constraints) analysis tool. Based on the situational analysis of the company and the author's understanding and CATWOE results, the results are obtained in Figure 2.

\begin{tabular}{|c|l|}
\hline $\mathbf{C}$ & Cmmunity, Corporate and Goverment \\
\hline $\mathbf{A}$ & President Director \& CEO, CHR Indosat, and CHR Ooredoo \\
\hline $\mathbf{T}$ & $\begin{array}{l}\text { - Changing: Organisation, Values, Brand and Vision } \\
\text { - Improvement Employee Capability }\end{array}$ \\
\hline $\mathbf{W}$ & $\begin{array}{l}\text { The fast Changes in information technology with platform digital } \\
\text { technology, changes in Government regulations, changes in business } \\
\text { with platform e-commerce, and the use of smartphones by end-user }\end{array}$ \\
\hline $\mathbf{O}$ & President Director \& CEO, CHR Indosat and Researcher \\
\hline $\mathbf{E}$ & $\begin{array}{l}\text { Regulations relating to employment (labor law), trade unions in } \\
\text { Indonesia, the threat of competitor (braindrain) }\end{array}$ \\
\hline
\end{tabular}

Figure 2. CATWOE Results.

The main customers who are the targets of PT Indosat are the Community, the Corporate, and the Government. The actors as the main actors in the enhancement model of the employee capabilities and the application of the company's new culture in realizing the competitiveness are the Managing Director, CHR Indosat, and CHR 
Ooredoo, GH Transformation, and Staff of GO Office. The Managing Director of Indosat remains the main driver.

The transformation carried out includes:

1. Changes: Organization, Value, Brand, and Vision.

2. Increased the employee capabilities.

The organizational change, the organizational structure, the value, the brand, and the vision have been explained in the previous chapter, as well as the improvement of the employee capabilities. The worldwide view: the changes in information technology quickly on the basis of digital technology, the changes in Government regulations, the changes in business on the basis of e-commerce, and the use of smartphone by the end-user.

\section{Conceptual Model}

The essence of SSM system thinking is the making of the conceptual models as the intellectual tools used to review and discuss the real-world situations that are considered to be problematic. The model in SSM is a model or a number of models of the systems or all systems of the human activity or activities that have the purpose.

The conceptual model is based on the predefined root definition. The activities from the system activities that have the purpose of the conceptual model are as follows: (1) Doing Analysis; (2) Operational Evaluation; (3) Vision and Mission; (4) Increased Employee Capabilities; (5) Efficiency and Accelerated Growth; (6) Transformation; (7) New Culture; (8) Creating New Market; (9) New Sales Scheme; (10) Increased Revenue and Profit.

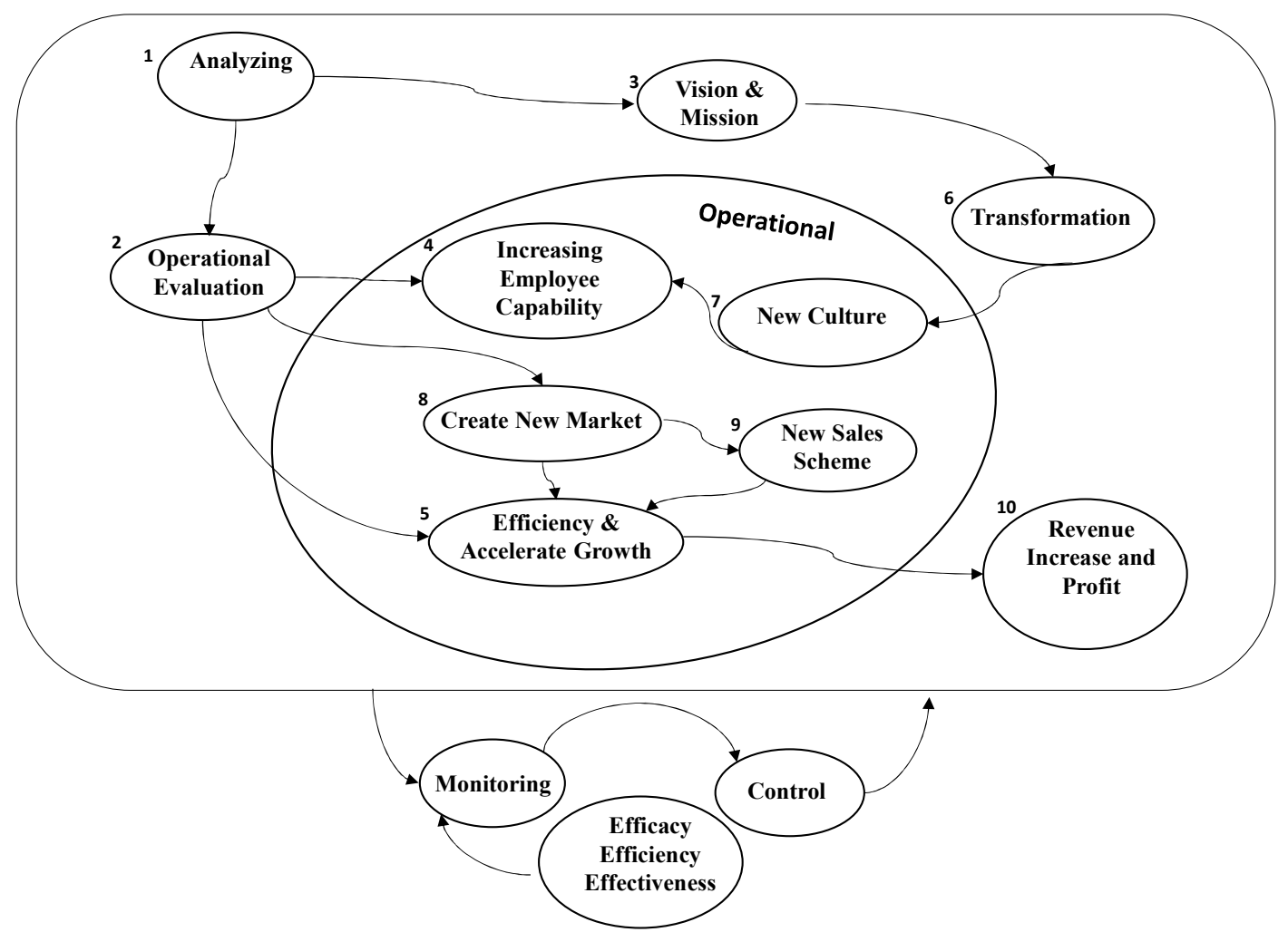

Figure 3. Conceptual Model.

4.1 Comparison of the Conceptual Model Activities with the Conditions in the Real World Comparison between the conceptual model activities and the conditions of the world results in the implementation or the activity gaps and requires the changes in activity, shown in Table 1. 
Table: 1 Comparison of the conceptual model activities with the conditions in the real world.

\begin{tabular}{|c|c|c|c|c|}
\hline No & $\begin{array}{c}\text { Conceptual Model } \\
\text { Activities } \\
\end{array}$ & $\begin{array}{l}\text { Conditions in the Real } \\
\text { World }\end{array}$ & Gaps that Occur & Proposed Corrective Action \\
\hline \multirow[t]{4}{*}{1} & \multirow[t]{4}{*}{ Doing Analysis } & Current economy & Difficult to predict & $\begin{array}{l}\text { Expansion of employee } \\
\text { knowledge economy }\end{array}$ \\
\hline & & $\begin{array}{l}\text { Development of digital } \\
\text { technology }\end{array}$ & Technology changes rapidly & $\begin{array}{l}\text { Managing Director / CEO with } \\
\text { the Vision for the Sustainability } \\
\text { of the Company }\end{array}$ \\
\hline & & $\begin{array}{l}\text { Regulations are issued by the } \\
\text { Ministry of Communication, } \\
\text { Bank Indonesia, and the } \\
\text { Financial Service Authority }\end{array}$ & \multirow{2}{*}{$\begin{array}{l}\text { Compliance with the } \\
\text { regulation is difficult to } \\
\text { fulfill }\end{array}$} & $\begin{array}{l}\text { Implementation of New Digital } \\
\text { Technology }\end{array}$ \\
\hline & & $\begin{array}{l}\text { The emergence of various } \\
\text { types of competitors }\end{array}$ & & $\begin{array}{l}\text { Cooperation between the } \\
\text { partners with the competitors }\end{array}$ \\
\hline \multirow[t]{9}{*}{2} & \multirow[t]{9}{*}{ Operational Evaluation } & \multirow{3}{*}{$\begin{array}{l}\text { Marketing program } \\
\text { according to the } \\
\text { development of digital } \\
\text { technology }\end{array}$} & $\begin{array}{l}\text { Limited implementation } \\
\text { capabilities }\end{array}$ & Cost Efficient and Effective \\
\hline & & & $\begin{array}{l}\text { New marketing programs } \\
\text { are slow execution }\end{array}$ & $\begin{array}{l}\text { Accelerating the execution of } \\
\text { the leading work programs }\end{array}$ \\
\hline & & & $\begin{array}{l}\text { Understanding the new } \\
\text { program is limited }\end{array}$ & Recruitment of experts \\
\hline & & \multirow{3}{*}{$\begin{array}{l}\text { Selling the services with } \\
\text { products and networks } \\
\text { according to the customer } \\
\text { needs }\end{array}$} & Limited access area & $\begin{array}{l}\text { Development of 4G / LTE } \\
\text { digital network access }\end{array}$ \\
\hline & & & Limited construction permit & Partners with the competitors \\
\hline & & & $\begin{array}{l}\text { Employee's understanding } \\
\text { of the digital product and } \\
\text { technology is not evenly } \\
\text { distributed }\end{array}$ & $\begin{array}{l}\text { Placing the Y / millennial } \\
\text { generation in each unit }\end{array}$ \\
\hline & & \multirow{2}{*}{$\begin{array}{l}\text { Repairing and maintaining } \\
\text { the network quality }\end{array}$} & $\begin{array}{l}\text { Cost Efficient / Budget } \\
\text { Optimization }\end{array}$ & Task Force that is efficient \\
\hline & & & Employees move in mobile & $\begin{array}{l}\text { Desktop or Smartphone based } \\
\text { remote system repair }\end{array}$ \\
\hline & & $\begin{array}{l}\text { Business Processes in all } \\
\text { operational units }\end{array}$ & $\begin{array}{l}\text { Business Processes that } \\
\text { change with the changing of } \\
\text { the organization, the } \\
\text { emergence of the new } \\
\text { products and the new } \\
\text { innovations }\end{array}$ & $\begin{array}{l}\text { Business process } \\
\text { documentation }\end{array}$ \\
\hline \multirow[t]{4}{*}{3} & Vision and Mission & & & $\begin{array}{l}\text { Leadership at each employee } \\
\text { level }\end{array}$ \\
\hline & Vision & $\begin{array}{l}\text { Becoming the leading digital } \\
\text { telecommunication company } \\
\text { in Indonesia (Indonesia's } \\
\text { leading digital telco } \\
\text { company) }\end{array}$ & \multirow{3}{*}{$\begin{array}{l}\text { Vision and mission have not } \\
\text { been understood by all } \\
\text { company employees }\end{array}$} & $\begin{array}{l}\text { Dissemination of vision and } \\
\text { mission through the digital } \\
\text { media }\end{array}$ \\
\hline & \multirow[b]{2}{*}{ Mision } & $\begin{array}{l}\text { Leading in providing the } \\
\text { Digital Touch Points }\end{array}$ & & $\begin{array}{l}\text { Dissemination of vision and } \\
\text { mission to the new employees }\end{array}$ \\
\hline & & $\begin{array}{l}\text { Strong players in the priority } \\
\text { area (Strong Player in Key } \\
\text { Geograpics) }\end{array}$ & & $\begin{array}{l}\text { The work program is interesting } \\
\text { for the fresh millennial } \\
\text { graduates, it is ready to use }\end{array}$ \\
\hline \multirow[t]{4}{*}{4} & \multirow[t]{4}{*}{$\begin{array}{l}\text { Improving the employee } \\
\text { capabilities }\end{array}$} & $\begin{array}{l}\text { Carrying out the assessment } \\
\text { towards the management and } \\
\text { the employees }\end{array}$ & $\begin{array}{l}\text { The results of the assessment } \\
\text { are not all employees in } \\
\text { accordance with the new } \\
\text { vision }\end{array}$ & $\begin{array}{l}\text { Recruiting the experience } \\
\text { employees according to the } \\
\text { vision of the } \mathrm{Y} / \text { Millennial } \\
\text { generation }\end{array}$ \\
\hline & & $\begin{array}{l}\text { Maintaining the employees } \\
\text { according to the company } \\
\text { needs }\end{array}$ & $\begin{array}{l}\text { Understanding the } \\
\text { competitiveness which is } \\
\text { not evenly distributed }\end{array}$ & $\begin{array}{l}\text { Dissemination of the company } \\
\text { strategies and priority programs }\end{array}$ \\
\hline & & $\begin{array}{l}\text { Recruiting the new } \\
\text { employees according to the } \\
\text { vision, the strategy, and the } \\
\text { work program }\end{array}$ & $\begin{array}{l}\text { Employees with limited } \\
\text { digital experience }\end{array}$ & $\begin{array}{l}\text { Recruiting the competitor, } \\
\text { startup, diaspora and telco } \\
\text { industry employees }\end{array}$ \\
\hline & & $\begin{array}{l}\text { The objective strategy of the } \\
\text { company must be elaborated } \\
\text { into the Key Performance } \\
\text { Measurement (IPM) }\end{array}$ & $\begin{array}{l}\text { Understanding of the } \\
\text { strategy implementation } \\
\text { with the balance score which } \\
\text { is not comprehensive }\end{array}$ & $\begin{array}{l}\text { Training on the implementation } \\
\text { of the balance score cards for } \\
\text { the Preparation of Performance } \\
\text { Indicators (KPI) / Individual } \\
\text { Performance Measurement } \\
\text { (IPM) }\end{array}$ \\
\hline
\end{tabular}




\begin{tabular}{|c|c|c|c|c|}
\hline No & $\begin{array}{c}\text { Conceptual Model } \\
\text { Activities }\end{array}$ & $\begin{array}{c}\text { Conditions in the Real } \\
\text { World }\end{array}$ & Gaps that Occur & Proposed Corrective Action \\
\hline \multirow{3}{*}{5} & \multirow{3}{*}{$\begin{array}{l}\text { Efficiency and } \\
\text { Accelerated Growth }\end{array}$} & $\begin{array}{l}\text { Carrying out the budget } \\
\text { control }\end{array}$ & $\begin{array}{l}\text { The program proposal must } \\
\text { be implemented }\end{array}$ & Training Financial Awareness \\
\hline & & $\begin{array}{l}\text { Operational efficiency } \\
\text { expense }\end{array}$ & $\begin{array}{l}\text { All work units receive a } \\
\text { reduction in budget }\end{array}$ & $\begin{array}{l}\text { Approved priority or mandatory } \\
\text { program }\end{array}$ \\
\hline & & $\begin{array}{l}\text { Prioritizing the marketing } \\
\text { and sales programs that } \\
\text { expand the market }\end{array}$ & Budget is limited & Program with the Cost Effective \\
\hline \multirow{6}{*}{6} & \multirow{6}{*}{ Transformation } & $\begin{array}{l}\text { Changes in the majority } \\
\text { ownership }\end{array}$ & Cultural differences & Understanding the differences \\
\hline & & Management changes & $\begin{array}{l}\text { Different lean leadership and } \\
\text { organizational styles }\end{array}$ & $\begin{array}{l}\text { Understanding the local culture } \\
\text { and reducing the bureaucracy }\end{array}$ \\
\hline & & $\begin{array}{l}\text { Changes in the company and } \\
\text { product brands }\end{array}$ & Old brands are still strong & $\begin{array}{l}\text { Intensive socialization of Re } \\
\text { Brands internally and externally }\end{array}$ \\
\hline & & $\begin{array}{l}\text { Changes in the vision and } \\
\text { the mission }\end{array}$ & $\begin{array}{l}\text { Uneven understanding of } \\
\text { strategies }\end{array}$ & $\begin{array}{l}\text { Explanation of strategy and } \\
\text { implementation is a work } \\
\text { program for all employees }\end{array}$ \\
\hline & & $\begin{array}{l}\text { Changes in the workspace } \\
\text { design }\end{array}$ & $\begin{array}{l}\text { New workspaces according } \\
\text { to the new values cannot be } \\
\text { implemented on all floors }\end{array}$ & $\begin{array}{l}\text { New workspaces are prioritized } \\
\text { for those who deal directly with } \\
\text { partners, customers, and those } \\
\text { which produce the digital-based } \\
\text { products }\end{array}$ \\
\hline & & Changes in how to dress & $\begin{array}{l}\text { Employees have not all } \\
\text { reflected the style of dress } \\
\text { according to the company's } \\
\text { new values }\end{array}$ & $\begin{array}{l}\text { Dissemination of regulations on } \\
\text { how to dress according to the } \\
\text { company's new values }\end{array}$ \\
\hline \multirow{6}{*}{7} & \multirow{6}{*}{ New Culture } & \multirow{6}{*}{$\begin{array}{l}\text { Implementing the new } \\
\text { company values }\end{array}$} & \multirow{6}{*}{$\begin{array}{l}\text { Implementation cannot be } \\
\text { done evenly due to the } \\
\text { employee attitude, the } \\
\text { budget efficiency, and the } \\
\text { central Ooredoo intervention }\end{array}$} & $\begin{array}{l}\text { New company logos and } \\
\text { service products and networks }\end{array}$ \\
\hline & & & & $\begin{array}{l}\text { New design work space, } \\
\text { product showroom and } \\
\text { customer service }\end{array}$ \\
\hline & & & & $\begin{array}{l}\text { I-work where the employees } \\
\text { can work at the work sites other } \\
\text { than in the office }\end{array}$ \\
\hline & & & & $\begin{array}{l}\text { Mobile-can work in various } \\
\text { locations in the office }\end{array}$ \\
\hline & & & & Dress young and polite \\
\hline & & & & $\begin{array}{l}\text { Employee speak-ups may and } \\
\text { can speak directly to the } \\
\text { Managing Director (CEO) }\end{array}$ \\
\hline \multirow[t]{2}{*}{8} & \multirow[t]{2}{*}{ Creating New Market } & $\begin{array}{l}\text { Conducting a collaboration } \\
\text { program with the growth of } \\
\text { "data" and with OTT (over } \\
\text { the top): Google, Facebook, } \\
\text { WhatsApp }\end{array}$ & $\begin{array}{l}\text { Impact of decreasing the } \\
\text { network quality }\end{array}$ & $\begin{array}{l}\text { Limiting the internet access } \\
\text { time and data per user, so that } \\
\text { the graph increases }\end{array}$ \\
\hline & & $\begin{array}{l}\text { Partner with the application } \\
\text { provider: video, music, } \\
\text { maps, transportation }\end{array}$ & $\begin{array}{l}\text { Impact of decreasing the } \\
\text { network quality }\end{array}$ & $\begin{array}{l}\text { Limiting the internet access } \\
\text { time and data per user, so that } \\
\text { the graph increases }\end{array}$ \\
\hline \multirow{3}{*}{9} & \multirow{3}{*}{ New sales scheme } & $\begin{array}{l}\text { Monthly incentives based on } \\
\text { the achievement }\end{array}$ & $\begin{array}{l}\text { Causing the jealousy among } \\
\text { the employees }\end{array}$ & $\begin{array}{l}\text { Incentives in accordance with } \\
\text { the target and measurable }\end{array}$ \\
\hline & & $\begin{array}{l}\text { Progressive incentives for } \\
\text { the dealers }\end{array}$ & $\begin{array}{l}\text { Dealers only focus on } \\
\text { adding the customers }\end{array}$ & $\begin{array}{l}\text { Incentives are given if the new } \\
\text { customers stand for } 3 \text { months } \\
\text { and the internet traffic and data } \\
\text { increase }\end{array}$ \\
\hline & & $\begin{array}{l}\text { Communication solutions: } \\
\text { companies, banking, } \\
\text { government, BUMN, and } \\
\text { smartcity }\end{array}$ & $\begin{array}{l}\text { Competing with the } \\
\text { competitors of the corporate } \\
\text { communication solutions }\end{array}$ & $\begin{array}{l}\text { Use of the latest digital } \\
\text { technology and the access via } \\
\text { smartphones }\end{array}$ \\
\hline \multirow{4}{*}{10} & \multirow{4}{*}{$\begin{array}{l}\text { Increased revenue and } \\
\text { profit }\end{array}$} & $\begin{array}{l}\text { Growth is above industry } \\
\text { Revenue grew positively }\end{array}$ & $\begin{array}{l}\text { Revenue growth tends to be } \\
\text { flat }\end{array}$ & $\begin{array}{l}\text { Acquisition of competitor } \\
\text { customers and creating new } \\
\text { markets }\end{array}$ \\
\hline & & \multirow{3}{*}{ Positive profile } & Operational cost increases & $\begin{array}{l}\text { Reducing the operational and } \\
\text { investment costs }\end{array}$ \\
\hline & & & Sensitive customer loyalty & $\begin{array}{l}\text { Economical package and bonus } \\
\text { programs }\end{array}$ \\
\hline & & & Operational cost increases & Reducing the operational costs \\
\hline
\end{tabular}

\subsection{Desired Changes}

Based on the gaps that occur, it is desirable to change the activities against:

1. Changes in the technology and the compliance with the regulations.

2. Implementation capacity.

3. Vision that has not been understood by the employees.

4. Understanding of competitiveness.

5. Limited budget.

6. Cultural differences.

7. The company's new values have not been evenly distributed.

8. Impact of decreasing the network quality. 
9. Dealers that only focus on adding the customers.

10. Growth in the revenue that tends to be flat.

Furthermore, the corrective actions are proposed to select the most suitable activities in realizing the competitiveness. The activities that have a purpose in the action for improvement will be chosen as the elements that will be prioritized to be the main determinant in enhancing the employee capabilities and the application of the company's new culture in realizing the competitiveness.

The employee capabilities refer to the abilities of the organization to complete its work process through the knowledge, the skills, the abilities, and the competencies of its employees. The capabilities can include the abilities to build and maintain the relationships with the customers; innovate and make transition to the new technology; develop the new products, services, and work processes; and meet the changes in the business, market and regulatory demands. Figure 4 shows that the capabilities of Indosat Ooredoo employees will experience a critical period, if the existing employees and the new recruits experiencing for $>5$ years are reallocated or obtain early retirement. The sustainable competitiveness must be maintained by recruiting the new fresh graduates who are in accordance with the company's vision and priority programs. The recruitment to prepare the employee regeneration with the unique capabilities that are rare, cannot be replicated and cannot be replaced.

Figure 4. Thinking Framework - Improvement.

\section{Employee Capability}

in a critical period if Existing and

Recruit New employees, with experience $>5$ years resign

Strategy

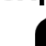

New Recruitment
Fresh Graduate
Inline with vision
and Priority
Program
Capability must be unique: Rarely Can't be imitated Can't be replace

Sustainable Competitivenes

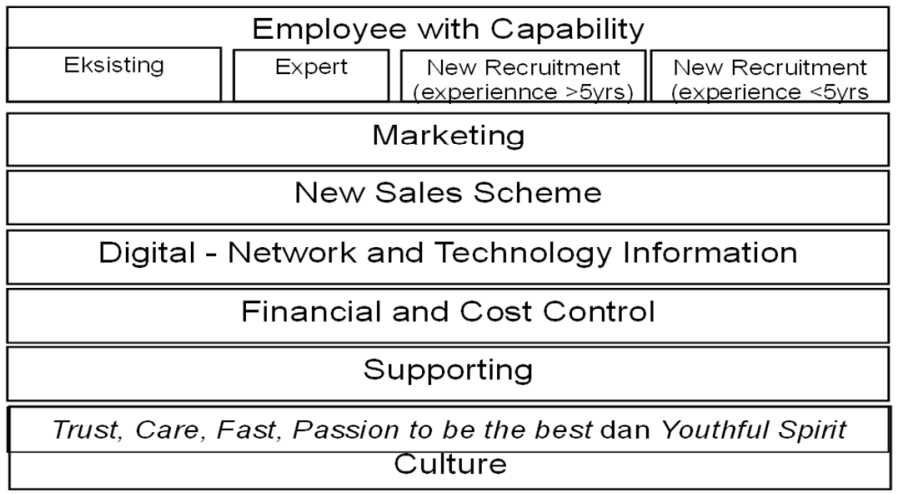

\section{Conclusion}

The conceptual model with the elements of activities showing that increasing the employee capabilities and implementing a new corporate culture are needed in carrying out the operations that realize the competitiveness which is the result of the Soft System Methodology. The capabilities of Indosat Ooredoo employees will experience a critical period if the existing employees and new recruits having the experience of $>5$ years are reallocated dor received the early retirement. The sustainable competitiveness must be maintained by recruiting new fresh graduates who are in accordance with the company's vision and priority programs. The recruitment to prepare the employee regeneration with the unique capabilities that is rare cannot be replicated and cannot be replaced.

\section{References}

Anand G, Peter T, Mohan VW, Tatikonda, Schilling DA. 2009. Dynamic capabilities through continuous improvement infrastructure. University of Illinois. Journal of Operations Management. 27 (6): 444-461.

Ardiansyah DO. 2016. Pengaruh Komunikasi terhadap Kinerja Karyawan dengan Dimediasi oleh Kepuasan Kerja (The Effect of Communication on Employee Performance by Mediated by Job Satisfaction). Jurnal Bisnis dan Manajemen (Journal of Business and Management). 3(1): 16-30.

Boniface C. 2011. Organization culture as driver of competitive advantage. Journal of Academic and Business Ethics. Canyon (US): Grand Canyon University.

Brahmasari IA, Suprayetno A. 2008. Pengaruh Motivasi Kerja, Kepemimpinan dan Budaya Organisasi terhadap Kepuasan Kerja Karyawan serta Dampaknya pada Kinerja Perusahaan (The Effect of Work Motivation, Leadership and Organizational Culture on Employee Job Satisfaction and Its Impact on Company Performance). Jurnal Manajemen dan Kewirausahaan (Journal of Management and Entrepreneurship). 10 (2): 124-135.

Checkland, P. \& Poulter, J. 2006. Learning for Action: A Short Definitive Account of Soft Systems Methodology 
and Its Use for Practitioners, Teachers and Students, p. 40.

Checkland P. 2009. Systems Thinking System Practice: Includes a 30 Year Retrospective. England (GB): John Willey and Sons Ltd.

Checkland P. 2009. Soft Systems Methodology in Action, England (GB): John Willey and Sons Ltd.

Dewi SK, Fitranto A. 2013. Pengaruh Lingkungan Kerja terhadap Kinerja Karyawan melalui Motivasi (The Effect of Work Environment on Employee Performance through Motivation). Jurnal Ilmiah Manajemen (Journal of Scientific Management). 1 (4): 1055-1065.

Dhermawan AANB, Sudibya IGA, Utama IWM. 2012. Pengaruh Motivasi, Lingkungan Kerja, Kompetensi, dan Kompensasi terhadap Kepuasan Kerja dan Kinerja Pegawai di Lingkungan Kantor Dinas Pekerjaan Umum Provinsi Bali (The Effect of Motivation, Work Environment, Competence, and Compensation on Job Satisfaction and Employee Performancein the Public Works Office of the Province of Bali). Jurnal Manajemen, Strategi Bisnis, dan Kewirausahaan (Journal of Management, Business Strategy, and Entrepreneurship). 6 (2): 173-184.

Febrianti S, Musadieq MA, Prasetya A. 2014. Pengaruh Reward dan Punishment terhadap Motivasi Kerja serta Dampaknya terhadap Kinerja (The Effect of Reward and Punishment on Work Motivation and Its Impact on Performance). Jurnal Administrasi Bisnis (Journal of Business Administration). 12 (1): 1-9.

Firmaiansyah D. 2014. Pengaruh Berbagi Pengetahuan terhadap Kinerja Karyawan Melalui Inovasi (The Effect of Knowledge Sharing on Employee Performance through Innovation). Jurnal Ilmu Manajemen (Journal of Management Science). 2(1): 128-139.

Kandou EE. 2017. Pengaruh Pelatihan dan Pengembangan Karyawan terhadap Produktivitas Kerja Karyawan (Studi pada PT Air Manado) (The Effect of Training and Employee Development on Employee Work Productivity (Study at PT Air Manado). Jurnal Acta Diurna (Journal of Acta Diurna). 2(3): 1-12.

Kotter JP. 1996. Leading Change. Massachusetts (US): Harvard Business Press.

Lewin K. 1947. Frontier in Group Dynamics: Concept, Method and Reality in Social Science; Social Equilibria and Social Change. Human Relations. 1(1): 5 - 41.

Neo BS, Chen G. 2007. Dynamic Governance: Embedding Culture, Capabilities and Changes in Singapore. Singapore (SG): World Scientific Publishing Co. Pte. Ltd.

Rachmawati Rr. W. 2013. Pengaruh Pelatihan dan Motivasi Kerja Terhadap Kinerja Karyawan PT Bank BJB Kantor Cabang Suci Bandung (The Effect of Training and Work Motivation on Employee Performance at PT BJB of Suci Branch Office Bandung). Jurnal Manajemen dan Pemasaran Jasa (Journal of Management and Service Marketing). 9(1): 1-16.

Sarwani. 2016. The Effect of Work Disclipine and Work Environment on the Performance of Employment. Sinergi (Synergy). 6 (2): 53-67.

Sofyan, DK. 2013. Pengaruh Lingkungan Kerja terhadap Kinerja Kerja Pegawai BAPPEDA (The Effect of the Work Environment on the Work Performance of BAPPEDA Employees). Malikussaleh Industrial Enginnering Journal. 2 (1): 18-23. 